\title{
Penerapan Latihan Rom Aktif Terhadap Kekuatan Otot Ekstremitas Bawah Pada Lansia Pasca Stroke
}

\author{
Rista Febriyani ${ }^{1 *}$, Dwi Fijianto ${ }^{2}$ \\ 1,2 Program Studi Diploma Tiga Keperawatan, Fakultas Ilmu Kesehatan Universitas \\ Muhammadiyah Pekajangan Pekalongan \\ *email: ristafebriyani88@gmail.com
}

\begin{abstract}
Stroke is a brain disorder that occurs due to damage to part of the brain caused by blocked blood vessels so that the flow of oxygen is not met properly. Stroke can cause death, paralysis, impaired speech, and decreased consciousness. The purpose of this case study was to increase lower extremity muscle strength by using ROM exercises. The method used was a case study by providing nursing care to two elderly post-stroke using Active Rom exercises. The results of this case study before doing active ROM on client I experienced a decrease in muscle strength with a percentage of 25 degrees 2 and client II experienced a decrease in muscle strength with a percentage of 25 degrees 2 . After doing active ROM there was an increase in muscle strength in client I with a percentage of 75 degrees 4 and on client II with a percentage of 50 degrees 3 . This case study can be said that the application of active range of motion (ROM) exercises can increase lower extremity muscle strength in the elderly after stroke. This case study is a consideration for nurses and other health workers to apply active ROM exercises in post-stroke patients.
\end{abstract}

Key words : Gerontic Nursing Care, Elderly Post-Stroke, Active ROM.

\begin{abstract}
Abstrak
Stroke adalah gangguan pada otak yang terjadi karena adanya gangguan kerusakan pada sebagian otak disebabkan karena pembuluh darah yang tersumbat sehingga aliran oksigen tidak terpenuhi dengan baik. Penyakit stroke dapat menyebabkan kematian, kelumpuhan, gangguan berbicara, dan menurunkan kesadaran. Tujuan dari studi kasus ini adalah untuk meningkatkan kekuatan otot ekstremitas bawah dengan menggunakan latihan ROM. Metode yang digunakan adalah studi kasus dengan memberikan asuhan keperawatan pada dua lansia pasca stroke dengan menggunakan latihan Rom Aktif. Hasil studi kasus ini sebelum dilakukan ROM aktif pada klien I mengalami penurunan kekuatan otot dengan presentase 25 derajat 2 dan klien II mengalami penurunan kekuatan otot dengan presentase 25 derajat 2 . Setelah dilakukan ROM aktif terjadi peningkatan kekuatan otot pada klien I dengan presentase 75 derajat 4 dan pada klien II dengan presentase 50 derajat 3. Kesimpulan studi kasus ini dapat disimpulkan bahwa penerapan latihan range of motion (ROM) aktif dapat meningkatkan kekuatan otot ekstremitas bawah pada lansia pasca stroke. Studi kasus ini sebagai pertimbangan bagi perawat dan tenaga kesehatan lain untuk menerapkan latihan ROM aktif pada pasien pasca stroke
\end{abstract}

Kata kunci: Asuhan Keperawatan Gerontik, Lansia Pasca Stroke, ROM aktif.

\section{Pendahuluan}

Stroke merupakan penyakit utama yang menyebabkan kematian diseluruh dunia dan penyebab utama ketiga kematian di Amerika Serikat, penyakit jantung dan segala kanker. Stroke dipertengahan abad ke-20 tingkat kematian lebih dari 700.000 orang pertahun dan 150.000 menyebabkan kematian. kemajuan dalam pengetahuan tentang patofisiologi stroke yang rekomendasi berdasarkan bukti terhadap pengelolaan pasien stroke (Dipiro. 2005 dalam Ode, 2017). 


\section{Prosiding Seminar Nasional Kesehatan Lembaga Penelitian dan Pengabdian Masyarakat Universitas Muhammadiyah Pekajangan Pekalongan}

Stroke di Indonesia merupakan penyakit nomer tiga yang mematikan setelah jantung dan kanker. Stroke terjadi pada sekitar 500.000 penduduk, sepertiga dapat pulih kembali, sepertiga lainnya mengalami gangguan fungsional ringan sampai mati, dan sepertiganya mengalami gangguan fungsional berat yang mengharuskan penderita terus beristirahat dibad (Haryono dkk, 2013).

Stroke merupakan kondisi terjadinya kerusakan pada sebagian otak disebabkan karena pembuluh darah yang tersumbat sehingga oksigen tidak terpenuhi dengan baik. Penyakit stroke merupakan penyebab kematian utama didunia serta dapat menyebabkan kelumpuhan, gangguan berbicara, menurunkan kesadaran dan kematian. Penyakit stroke ini dapat terjadi karena gangguan penyakit seperti hipertensi, jantung, dan diabetes militus (Haryono dkk, 2013). Stroke merupakan tanda-tanda klinis yang berkembang cepat akibat gangguan otak global (atau fokal) dengan gejala-gejala yang berlansung selama 24 jam atau lebih dan dapat menyebabkan kematian tanpa adanya penyebab lain yang jelas selain vaskuler (WHO, 2005 dalam Ode, 2017).

Shimberg (1998) dalam Haryono (2013) menyatakan bahwa stroke merupakan penyakit serebrovakuler (pembuluh darah otak) yang ditandai dengan kematian jaringan otak (infark serebral), hal tersebut terjadi karena kurangnya aliran darah dan oksigen keotak atau keadaan di mana sel-sel otak mengalami kerusakan, karena tidak mendapatkan oksigen dan nutrisi yang cukup (Haryono dkk, 2013)

Sustrani dkk (2004) dalam Haryono (2013) mengatakan stroke merupakan serangan otak yang terjadi secara tiba-tiba dengan akibat kematian atau kelumpuhan sebelah bagian tubuh. Berat atau ringannya akibat serangan stroke tersebut sangat bermacam variasi, tergantung lokasi dan luas daerah otak yang rusak. Bila aliran darah terputus hanya pada area yang kecil atau terjadi pada daerah otak yang tidak rawan, efeknya ringan dan berlangsung sementara. Sebaliknya bila aliran darah terputus pada daerah yang luas atau bagian otak vital, terjadi kelumpuhan yang parah sampai mengalami kematian (Haryono dkk, 2013).

Kekuatan otot pada lansia penderita stroke berhubungan dengan masalah fisik yang muncul yaitu hilangnya kesadaran selama stroke, inkontinensia, kelumpuhan atau kelemahan otot, sehingga pasien mengalami gangguan gerak karena adanya kerusakan susunan saraf pada otak dan kekakuan otak otot serta sendi (Wakhidah dkk, 2019).

Tindakan untuk mingkatkan kekuatan otot dengan pengukuran kekuatan otot dapat dilakukan dengan menggunakan penguji otot secara manual yang disebut dengan MMT (manual muscie testing) (Yuliastuti, 2011 dalam Ananda, 2017).

Tindakan keperawatan yang dapat dilakukan pada lansia penderita stroke untuk mencegah kekakuan ekstremitas bawah dan kekuatan otot pada lansia dapat meningkat dengan latihan ROM aktif. Tindakan keperawatan yang telah diambil dari intervensi NANDA (2011) dalam Nurtanti \& Ningrum (2018) yaitu mengajarkan pasien bagaimana latihan ROM aktif, merubah posisi dan berikan bantuan jika diperlukan dan didukung dengan teori Eldawati (2011) dalam Nurtanti \& Ningrum (2018) ROM adalah latihan gerak sendi untuk meningkatkan aliran darah parifer dan mencegah kekakuan otot dan sendi (Nurtanti S, Ningrum W. 2018). 


\section{Prosiding Seminar Nasional Kesehatan Lembaga Penelitian dan Pengabdian Masyarakat Universitas Muhammadiyah Pekajangan Pekalongan}

ROM merupakan suatu latihan yang dilakukan untuk mempertahankan kemampuan menggerakkan persendian secara normal. Rom aktif memungkinkan terjadi gerakan pada seluruh struktur yang berpengaruh diantaranya, permukaan sendi, otot, kapsul sendi, fasia, pembuluh darah dan saraf (Erwanto, 2017 dalam Ananda, 2016). Latihan rentang gerak (ROM) dapat mencegah terjadinya kontraktur, atropi otot, meningkatkan peredaran darah ke ekstremitas, mengurangi kelumpuhan vaskuler, dan memberikan kenyamanan bagi klien. Perawat harus mengajarkan, mempersiapkan, dan membantu klien untuk latihan ROM yang mencakup semua sendi.

Berdasarkan latar belakang, penulis tertarik untuk melakukan penerapan terkait ROM aktif pada pasien lansia pasca stroke, dengan harapan dengan dilakukan ROM akan memberikan dampak pada kekuatan otot.

\section{Metode}

Penelitian ini merupakan penelitian studi kasus. Pengambilan responden berdasarkan tingkat kekuatan otot pada pasien lansia pasca stroke. Lokasi pengambilan kasus berada di desa pagergunung kecamatan ulujami kabupaten pemalang. Lamanya asuhan keperawatan selama 3 minggu. Asuhan keperawatan dilakukan setiap pagi dan malam 12 kali pertemuan dalam 3 minggu.

\section{Hasil dan Pembahasan}

\section{Hasil}

Fokus implementasi keperawatan yang dilakukan dalam studi kasus ini adalah penerapan latihan ROM aktif terhadap kekuatan otot ekstremitas bawah pada lansia pasca stroke. Implementasi yang dilakukan untuk meningkatkan kekuatan otot adalah sebagai berikut :

1) Kasus I

Pertemuan pertama hingga pertemuan keenam melakukan implementasi yaitu melakukan pengkajian kekuatan otot. Monitor TTV, melatih ROM aktif. Hasil data subjektif kaki kaku, lemas, susah beraktivitas. Data Objektif kekutana otot dengan presentase 25 derajat 2.

Pertemuan ketujuh hingga pertemuan kesembilan melakukan implemetasi yaitu melakukan pengkajian kekuatan otot, monitor TTV, melatih ROM aktif. Hasil data subjektif kaki kaku berkurang, lemas berkurang. Data objektif kekutan otot yang didapatkan dengan presentase 50 derajat 3.

Pertemuan kesepuluh hingga pertemuan kedua belas melakukan implementasi yaitu melakukan pengkajia, monitor kekuatan otot, monitor TTV, melakukan ROM aktif. Hasil data subjektif kaki tidak kaku, sudah beraktivitas seperti biasa. Data objektif didaptkan kekuatan otot dengan presentase 75 derajat 4.

2) Kasus II

Pertemuan pertama hingga pertemuan kesembilan melakukan implementasi yaitu melakukan pengkajian, monitor kekuatan otot, monitor TTV, melakukan ROM aktif. Hasil data subjektif kaki kaku, merasa lemas, susah beraktivitas, susah tidur. Data objektif didaptkan kekuatan otot dengan presentase 25 derajat 2. 


\section{Prosiding Seminar Nasional Kesehatan Lembaga Penelitian dan Pengabdian Masyarakat Universitas Muhammadiyah Pekajangan Pekalongan}

Pertemuan kesepuluh hinggan kedua belas melakukan implementasi yaitu melakukan pengkajian, monitor kekuatan otot, monitor TTV, melakukan ROM aktif. Hasil data subjektif kaki kaku berkurang, lemas berkurang, beraktivitas sedikit demi sedikit, susah tidur berkurang. Data objektif didaptkan kekuatan otot dengan presentase 50 derajat 3.

\section{Pembahasan}

Penulis akan menguraikan gambaran hasil asuhan keperawatan gerontik dikeluarga Tn. C dan Tn. S. Fokus implemetasi yang dilakukan adalah untuk meningkatkan kekuatan otot ekstremitas bawah untuk menyelesaikan masalah keperawatan hambatan mobilitas fisik pasca stroke.

1) Pengkajian

Pengkajian pada Tn. C dan Tn. S dilakukan observasi, pemeriksaan fisik, dan wawancara. observasi didapatkan dari pengamatan langsung pada $\mathrm{Tn}$. $\mathrm{C}$ dan $\mathrm{Tn}$. $S$ yang bertujuan memperoleh data objektif. Hasil pengkajian yang di dapat kedua klien mengalami kelemahan otot pada ekstremitas bawah yang diakibatkan karena stroke.

Penulis membahas tentang asuhan keperawatan gerontik pada lansia pasca stroke dengan kelemahan otot. berdasarkan hasil pengkajian yang didapatkan data pada klien I yaitu berinisial Tn.C, laki-laki, usia 87 tahun mengeluh kaki kaku, sulit digerakkan, sering mengalami kesemutan, data obyektif didapatkan hasil pengukuran kekuatan otot prestase 25 derajat 2 dan klien II berinisial Tn.S laki-laki , usia 90 tahun mengeluh kaki kaku , sulit digerakkan, sering mengalami kesemutan, data obyektif didapatkan hasil pengukuran kekuatan otot prestase 25 derajat 2. Data yang di dapatkan dari klien I dan klien II menunjukkan bahwa klien I dan klien II menderita stroke.

Tanda dan gejala yang muncul sesuai dengan teori menurut Mutiarasari D (2019) pada penderita stroke seperti kelemahan pada kaki, kelelahan, serta gangguan beraktivitas. Menurut Nurarif dan Kusuma (2015) mengatakan penderita mengalami gejala stroke secara dadakan dan gejala tersebut sebagai rambu awal atau peringatan pertama dari penanganan stroke. Data pengkajian yang penulis dapatkan sesuai dengan penelitian Haryono dkk (2017) yang menyatakan bahwa pasien stroke mengalami kaki kaku, susah beraktivitas, mudah lelah, dan sering kesemutan dengan presentase 25 derajat 2.

2) Diagnosa keperawatan

Penulis menegakan diagnosa pada kedua klien yaitu hambatan mobilitas fisik. kedua klien memiliki kesamaan keluhan utama yaitu mengalami kaku pada otot dan sering kesemutan. Hal ini sesuai dengan teori yang dijelaskan oleh (Nurarif dan Kusuma, 2015) yang menjelaskan masalah yang muncul pada penderita pasca stroke yaitu diantaranya, hambatan mobilitas fisik, ketidakefektifan perfusi jaringan perifer, kurang efektifnya koping keluarga, kurang efektifnya pengelolaan kesehatan dalam keluarga, resiko ketegangan peran pelaku, intoleransi aktivitas. 


\section{Prosiding Seminar Nasional Kesehatan 2021 Lembaga Penelitian dan Pengabdian Masyarakat Universitas Muhammadiyah Pekajangan Pekalongan}

Diagnosa keperawatan utama pada kedua klien adalah hambatan mobilitas fisik. Hambatan mobilitas fisik merupakan keterbatasan pada pergerakan fisik tubuh atau pada salah satu ekstremitas secara mandiri dan terarah (Wicaksono $P$, 2017) Sesuai dari data yang telah ditemukan dan berdasarkan data fokus dalam pengkajian maka diagnosa keperawatan baik itu Tn. C maupun Tn. S adalah hambatan mobilitas fisik. mobilitas fisik merupakan keterbatas dalam gerakan fisik dari satu atau lebih ekermitas secara mandiri. Diagnosa keperawatan ini dimunculkan sesuai berdasarkan batasan karakteristik pada (Nurarif dan Kusuma, 2015) yaitu hambatan mobilitas fisik, ditandai dengan keluhan pada klien I dan klien II mengatakan kakupada kaki dan hasil presentase kekutan otot 25 derajat 2.

\section{3) Intervensi keperawatan}

Penulis menyusun rencana keperawatan untuk meningkatkan kekuatan otot pada diagnose keperawatan hambatan mobilitas fisik. Tujuan yang diharapkan adalah setelah dilakukan tindakan keperawatan selama 12 kali kunjungan masalah mobilitas fisik pada klien dapat teratasi dengan kriteria hasil klien mampu meningkatkan kekuatan otot pada ektermitas bawah. Intervensi penulis rencanakan adalah dengan latihan ROM aktif. Adrian dan Nurfatma (2019) menjelaskan bahwa latihan ROM dapat meningkatkan kekuatan otot pada ektremitas bawah pada lansia pasca stroke dengan prestase 25 derajat 2 menjadi prestase 50 dan 75 derajat 3 dan 4.

Rencana tindakan keperawatan yang disusun adalah: monitor TTV, Mengukur kekuatan otot, ajarkan latihan ROM aktif, menganjurkan pasien tetap rileks. Hal ini sesuai dengan yang dijelaskan menurut Nurarif $\mathrm{H}$.A dan Kusuma $\mathrm{H}$ (2015), bahwa latihan ROM aktif jika dilakukan sedini mungkin dan di lakukan dengan benar secara terus-menerus akan memberikan dampak pada kekuatan otot. Penyusunan rencana keperawatan harus didasari dengan penyusunan tujuan bersama dengan keluarga sehingga lebih efektif dalam memberikan tindakan keperawatan.

4) Implementasi keperawatan

Impementasi yang telah penulis lakukan pada klien I dan klien II sesuai dengan rencana keperawatan dengan menerapkan latihan ROM aktif untuk meningkatkan kekuatan otot. Peningkatan kekuatan otot di ukur menggunakan pengukuran kekuatan otot Ester (1998).

Range Of Motion (ROM) adalah latihan yang dilakukan untuk mempertahankan atau memperbaiki tingkat kemampuan untuk menggerakan persendian secara normal untuk meningkatkan massa otot dan tonus otot, (Ananda, 2017). Klien I didapatkan presentase kekuatan otot 25 derajat 2 menjadi perstase 75 derajat 4 pada klien II didapatkan presentase kekuatan otot 25 derajat 2 menjadi persentase 50 derajat 3, klien I sudah ada peningkatan pada ektermitas bawahnya dan klien II sudah mampu berjalan sendiri walaupun masih menggunakan alat bantu. 


\section{Prosiding Seminar Nasional Kesehatan 2021 Lembaga Penelitian dan Pengabdian Masyarakat Universitas Muhammadiyah Pekajangan Pekalongan}

5) Evaluasi keperawatan

Evaluasi yang dilakukan berdasarkan subyektif, obyektif, assessement, dan planning. Evaluasi yang di dapatkan setelah latihan ROM aktif, klien dan keluarga telah memahami gerakan yang telah contohkan. Klien menunjukkan respon verbal kognitif yaitu klien dan keluarga mampu memahami gerakan ROM aktif dan melakukannya setiap dua hari sekali selama 10 menit dalam 3 minggu. Evaluasi keperawatan yang didapatkan diagnosa keperawatan hambatan mobilitas fisik teratasi. Menurut Ananda (2017) melatih ROM aktif sangat efektif untuk meningkatkan kekatan otot pada lansia pasca stroke dengan hambatan mobilitas fisik.

Hasil di dapatkan antara Tn. C dan Tn. S menunjukkan adanya peningkatan kekuatan otot yang ditunjukkan dengan data subyektif yang didapat yaitu klien mengatakan mampu berjalan tanpa alat bantu dan tanpa bantuan keluarga. Sedangkan data obyektif yang didapat pada klien : klien dapat berjalan tanpa bantuan dengan presentase 50 dan 75 dengan derajat 3 dan 4 (Ester, 1998).

6) Ketebatasan penulisan

Studi kasus pemberian latihan ROM aktif pada lansia pasca stroke di Desa Pagergunung dan Bumirejo Kecamatan Ulujami sudah dilakukan sesuai prosedur. Selama melakukan asuhan keperawatan pada kedua klien terdapat beberapa kendala yaitu saat mengajarkan latihan ROM gerakannya banyak jadi kedua klien sering lupa. Klien kedua lebih mengalami kesulitan karena faktor usia lebih dari 90 tahun dibandingkan klien pertama saat diajarkan ROM aktif lebih memahami gerakan tersebut.

\section{Kesimpulan}

Berdasarkan hasil studi kasus penulis dapat menyimpulkan bahwa ROM aktif meningkatkan kekuatan otot pada kedua klien lansia pasca stroke. Hasil pengkajian yang didapatkan pada kasus I didapatkan data klien mengatakan kaki kaku, mudah lelah, susah beraktivitas, sering kesemutan, dan didaptkan data obyektif klien tampak lelah, TD $120 / 60 \mathrm{mmHg}$, RR 22x/menit, S 35, $5^{\circ} \mathrm{C}, \mathrm{N} 89 x /$ menit dengan kekuatan otot presentase 25 derajat 2 . Kasus II didapatkan data klien mengatakan kaki kaku, mudah lelah, susah beraktivitas, sering kesemutan dan didapatkan data obyektif klien tampak lelah dan susah beraktivitas, TD $160 / 900 \mathrm{mmHg}$, RR $23 x /$ menit, S $36,5^{\circ} \mathrm{C}$, $\mathrm{N} 98 \mathrm{x} /$ menit dengan kekuatan otot presentase 25 derajat 2.

Tersusunnya diagnosa pasca stroke, pada klien I dan klien II yaitu Hambtan mobilitas fisik dengan menurunnya kekuatan otot dan didapatkan hasil data obyektif fan subyektif klien I dan klien II mengatakan kaki kaku dan sering kesemutan. Rencana tindakan keperawatan yang disusun adalah: melakukan Monitor vital sign sebelum dan sesudah pemberian ROM aktif, mengukur kekuatan otot, ajarkan latihan ROM aktif, anjurkan pasien tetap rileks. Implementasi yang penulis lakukan sudah sesuai dengan rencana keperawatan dalam asuhan keperawatan gerontik pada pasien pasca stroke melakukan TTV sebelum dan sesudah melakukan tindakan, mengkaji kekuatan otot setelah melakukan tindakan, mengajarkan ROM aktif setiap pertemuan dalam 10 menit. Di dapatkan evaluasi ke dua klien yang mengalami hambatan 


\section{Prosiding Seminar Nasional Kesehatan 2021 Lembaga Penelitian dan Pengabdian Masyarakat Universitas Muhammadiyah Pekajangan Pekalongan}

mobilitas fisik teratasi ditunjukkan dengan adanya peningkatan kekuatan otot pada kedua klien, klien I kekuatan otot presentase 75 derajat 4 dari presentase 25 derajat 2 dan klien II kekuatan otot presentase 50 derajat 3 dari presentase 25 derajat 2.

\section{Saran}

Berdasarkan hasil studi kasus penulis memberikan saran sebagai berikut, Bagi klien dapat menjadi terapi non farmakologi untuk meningkatkan kekuatan otot dengan latihan ROM aktif secara mandiri, Bagi perkembangan ilmu pengetahuan dan teknologi keperawatan dapat menambah literature dalam perawatan pada pasien pasca stroke dengan menggunakan latihan ROM aktif, dan bagi tenaga kesehatan diharapkan dapat menjadi alternatif tindakan non farmakologi untuk menambah kekuatan otot pada pasien lansia pasca stroke dengan latihan ROM aktif.

\section{Referensi}

[1] Ananda P. I. (2017). Pengaruh Range Of Motion (ROM) Terhadap Kekuatan Otot Pada Lansia Bedrest Di PSTW Budhi Mulia 3 Margaguna Jakarta Selatan, Diambil dari https://scholar.google.co.id/.

[2] Andrian \& Nurfatma S. (2019). Real in Nursing Journal (RNJ) Pengaruh Latihan Range Of Motion (ROM) Aktif Terhadap Peningkatan Kekuatan Otot Ekstremitas Bawah Lansia.2(3)118 Diambil dari https://ojs.fdk.ac.id/index.php/Nursing/index.

[3] Andrian \& Nurfatma S. (2019). Real in Nursing Journal (RNJ) Pengaruh Latihan Range Of Motion (ROM) Aktif Terhadap Peningkatan Kekuatan Otot Ekstremitas Bawah Lansia.2(3)118 Diambil dari https://ojs.fdk.ac.id/index.php/Nursing/index

[4] Ester M. (1998). Pengkajian Gerontologi. Jakarta: Buku Kedokteran EGC

[5] Haryono R., Setianingsih S. (2013). Awas Musuh-musuh Anda Setelah Usia 40 Tahun. Yogyakarta: Gosyen Publishing.

[6] Lukman., Ningsih N. (2009). Asuhan Keperawatan pada Klien dengan Gangguan Muskuloskeletal. Jakarta: Salemba Medika.

[7] Nurarif H.A \& Kusuma H. (2015). Aplikasi Keperawatan Berdasarkan Diagnosa Medis dan Nanda Nic-Noc. Yogyakarta: MediAction.

[8] Nursalam. (2017). Metodologi penelitian ilmu keperawatan :pendekatan praktis. Jakarta : Salemba Medika.

[9] Nurtanti S \& Ningrum W. (2018). Efektifitas Range Of Montion (ROM) Terhadap Peningkatan Kekuatan Otot pada Pasien Penderita Stroke. Jurnal Keperawatan GSH. 7(1)14-18. https://scholar.google.co.id/.

[10] Ode L. S. (2017). Asuhan Keperawatan Gerontik: Berstandar Nanda, NIC, NOC Dilengkapi Teori dan Contoh Kasus Askep. Yogyakarta: Nuha Mendika. 


\section{Prosiding Seminar Nasional Kesehatan 2021 Lembaga Penelitian dan Pengabdian Masyarakat Universitas Muhammadiyah Pekajangan Pekalongan}

[11] Wakhidah N. et al. (2019). Perbedaan Latihan Kekuatan Otot Pasien Pasca Stroke yang memperoleh berbagai dukungan keluarga. Jurnal Ilmiah Permas, 9(3), 249258. https://scholar.google.co.id/.

[12] Wicaksono P. (2017). Upaya Peningkatan Mobilitas Fisik Pada Pasien Stroke Non Hemorogik. Diambil dari : https://eprints.ums.ac.id 